\title{
Industry-Internship Program for Biotechnology Under-graduates- Enabling the Student-Workforce for Better Employability
}

\section{Zabin K. Bagewadi, Shivalingsarj V. Desai*, Uday M. Muddapur, Deepak Yaraguppi, Basavaraj Hungund, , Laxmikant Patil, Veeresh Hombalimath, Anil R.Shet, Sharanappa Achappa and Gururaj Tennalli.}

Department of Biotechnology, KLE Technological University, Hubballi- 580 031, Karnatak ( India).

*Corresponding Author: email- desaisv@kletech.ac.in

Phone: +91 9886172994

\section{ABSTRACT :}

Industry-Internships are emerging as a trend in academic programs given the thrust for skill enhancements of students, making them industry-ready and placements. The present study gives an account of full-time industryinternship program at Department of Biotechnology, KLE Technological University, Hubballi. The key objectives of the program were to expose the students to industry work scenario, provide an opportunity to work on live projects and enhance the placements through the conversion of internships to placements. The program was for a duration of six months as part of their VIII semester with 20 credits, which included industry training and project modules. A structured rubrics-based assessment in terms of in-semester and end semester was performed. The students worked as interns in several Biotechnology-led enterprises. Industry, students and internship co-coordinator of the institute were the key stake-holders in the process. The students opined that the program helped them making an informed choice of their career and made them industry-ready. The number of internships program recorded a steady increase year-onyear which reflects the relevance of from students' perspective. The program was instrumental in addressing eight program outcomes The industries in-turn were satisfied with the performance, team coherence and attitude of the interns. The program churned out to be a win-win model for both the students and the participating industries.

Keywords: Industry-Internship, skills, practical training.

\section{INTRODUCTION}

Internship also referred to as 'Industrial training ', 'work placement' or 'practical' is a program that bridges classroom and workplace. Internship programs are introduced to offer a real time work exposure students and enabling to bridge the education - job skill mismatch, which is considered as a major factor causing graduate unemployment. Biotechnology is regarded as a sun-rise sector with significant potential in terms of economics and societal outreach in the years to come. The industry is predominantly knowledge-based and leverages on trained talented pool with skill-sets, domain experience and desirably with all the components needed to translate scientific discovery into commercial products. (Collins, 2002). The recent trend indicates that, the Biotechnology companies, more so start-ups, are reluctant to invest time and money in training the workforce and prefer to hire trained professionals ready to hit the ground running. (Nugent and Kulkarni, 2013).

Biotechnology being a blend of biology and engineering principles, research $\&$ development leading to innovations remains at the core, like other engineering disciplines. This calls for a hands-on experience and practical experience of the personnel involved. IndustryInternships are believed to be the best for outside the classroom learning experience (Burnet, 2003)

Biotechnology-based companies are confronted with critical workforce gaps in the below mentioned sub-sectors of bio-manufacturing:

1. Bio-based manufacturing- Biotechnologists specialized in high-throughput screening of strains and their production are few in number.

2. Bio-process engineering- Engineers trained in fermentation and bio-processing are difficult to be available.

3. Optimization process- Professionals with working experience of Design of Experiment and application of statistics for optimization of media and process parameters are in great demand. (Philip, 2018). 
4. Biologics- Biotechnologists with knowledge and experience of working in Bio-similars, recombinant DNA technology and expression studies are most sought-after in the industry (Carlson, 2016).

Conventional Biology education has remained divided into distinct domains (Boany, Zoology, Microbiology and Biochemistry). The present day academic scenario has been hard-pressed to adopt multi and interdisciplinary approach to cater to the demands of industry needs and thereby improve the placements of the students. Biotechnology industry has a limited need for deeply specialized scientists but rather has good space for a technically trained workforce. Most often academic programs are impart training by discipline and not by problem-solving or experiential mode, which typically requires hands-on skillsets learny by practical approach. This challenge of higher education to bring in the traits into academics can well be achieved by industry-internship approach (Mascarelli, 2013). An Integrated -Internship Program was adopted by University of South Florida and Shih Chien University through University-Industry cooperation which resulted in students expressing their satisfaction of learning through experiential mode. (Chang and Chu, 2009).

A systematic approach of Structure Equation Modeling was employed by National Kaohsiung University, Taiwan wherein the data collected through questionnaire revealed that the students were positively influenced towards their career goals by internship module (Chen and Shen, 2012).

In this context, Industry-Academia interaction assumes prominent role in facilitating the internship and mentoring of the students.

Internships are the most practical ways for employers and students to prepare for the coming years as working professionals and invest in their

futures. The significance of the industry-Internship program is that it bridges the gap between industry and academia and provides a career development opportunity for students and helps in building a good community of skilled professionals (Khan and Gogos, 2013 ).

A. Internship as a win-win model for students and industries.

The industry-Internship brings-in several advantages and provides a win-win situation to both the stake-holders, students' and industry as shown in TABLE 1. STUDENTS AND INDUSTRY PERSPECTIVES OF INTERNSHIP PROGRAM

\begin{tabular}{|l|l|l|}
\hline $\begin{array}{l}\text { Sl. } \\
\text { No. }\end{array}$ & Students' Perspective & Industry Perspective \\
\hline 1 & $\begin{array}{l}\text { Provides to work in real- } \\
\text { life scenarios }\end{array}$ & $\begin{array}{l}\text { Infusion of new ideas } \\
\text { and thought process } \\
\text { through fresh, young and } \\
\text { enthusiastic interns. }\end{array}$ \\
\hline
\end{tabular}

\begin{tabular}{|c|c|c|}
\hline 2 & $\begin{array}{l}\text { Get a chance to work on } \\
\text { live projects. }\end{array}$ & $\begin{array}{l}\text { No formal commitment } \\
\text { or binding to have the } \\
\text { interns on roll after } \\
\text { internship tenure. }\end{array}$ \\
\hline 3 & $\begin{array}{l}\text { Get an opportunity to } \\
\text { apply, test and } \\
\text { appreciate the } \\
\text { theoretical aspects learnt } \\
\text { during academics onto } \\
\text { projects in industry. }\end{array}$ & $\begin{array}{l}\text { Provision of making an } \\
\text { informed choice } \\
\text { regarding prospective } \\
\text { employee, if interns } \\
\text { need to be recruited. }\end{array}$ \\
\hline 4 & $\begin{array}{l}\text { Helps in honing the soft } \\
\text { and hard skills. }\end{array}$ & $\begin{array}{l}\text { Saves on efforts, time } \\
\text { and resources incurred } \\
\text { on fresh recruitment. }\end{array}$ \\
\hline 5 & $\begin{array}{l}\text { A short spell of industry } \\
\text { training gives a feel of } \\
\text { research experience , } \\
\text { thus enabling to make } \\
\text { an informed and } \\
\text { conscious choice for } \\
\text { career path. }\end{array}$ & $\begin{array}{l}\text { Brings in a sense of } \\
\text { presence in academic } \\
\text { corridors } \\
\text { enhances the repute of } \\
\text { the company. }\end{array}$ \\
\hline 6 & $\begin{array}{l}\text { Practical training and } \\
\text { work-experience in } \\
\text { industry boosts their } \\
\text { confidence and makes } \\
\text { them more industry- } \\
\text { ready. }\end{array}$ & $\begin{array}{l}\text { Collaboration with the } \\
\text { academic institutes } \\
\text { increases the networking } \\
\text { resulting in long- } \\
\text { standing relationships in } \\
\text { a healthy and mutually } \\
\text { beneficial way. }\end{array}$ \\
\hline 7 & $\begin{array}{l}\text { May avail financial } \\
\text { assistance as stipend } \\
\text { during the tenure }\end{array}$ & $\begin{array}{l}\text { Can leverage on } \\
\text { harnessing the top talent } \\
\text { from academia and } \\
\text { induct. }\end{array}$ \\
\hline
\end{tabular}

Students consider industry internship as a first step towards employment with the chances of internship to jobs conversion being high. The program is often known to foster team-work and problem solving skills in students and add to their work experience.( Cannon \& Arnold, 1998., Hite \& Bellizi, 1986). The industry-internship program acts as a pre-recruitment exercise for the industries and benefits in terms of source of inexpensive labor, cost effective and flexible human resource (Neuman, 1999, Cates-Mclver, 1999, Miner and Crane, 1995 and Busby et al, 1997)

\section{MeThodologY:}

A. Genesis and Objective of Industry-Internship Program:

The idea of adopting full-time Industry-internship as part of graduate program in KLE Technological University was conceived in 2014-15. The key objectives of the program were:

1. To expose the students to industry work scenario.

2. Provide an opportunity to work on live projects

3. Enhancing the placements through the conversion of internships to placements. 
The program was introduce after taking the inputs from industry stake-holders and alumni into consideration. Accordingly, initially a five-month tenure of industryinternship was brought in as part of VIII semester. Based on the suggestions from the stake-holders the tenure was extended to six months to facilitate better training and association with the industries offering internship. The process begins in as early as VII semester with the interested students exploring their chances of internship in various industries of their choice and interest. The Department of Biotechnology also arranges for some internship opportunities based on their earlier rapport with the industries and alumni working in different organizations. After initial informal communications with the organizations, a formal letter of consent from the industry regarding the confirmation of industry-internship for the students selected is being taken.

As a run-up to industry-internship program during the VIII semester, the students are formally trained to inculcate and hone their domain skill-sets through well structured themebased Mini and Minor projects during their V and VI semesters respectively (Shet et al., 2017 and Shet et al., 2017).

B. Key features of industry-internship at KLE Technological University

1. The internship program comprises of six months of full-time tenure generally from January till June which coincide with the beginning and closure of the semesters.

2. A total of 20 credits is allotted to the program of which industry-training is of 6 credits and industry projects comprising 14 credits.

3. To facilitate the program, a bare minimum number of courses and laboratories are retained for the VIII semester.

4. The minor exams are conducted upfront in the beginning of the semester and Semester-End Exams (SEE) are scheduled on either Saturday/Sunday to avoid hindrances during the tenure.

5. Rubrics-based assessment and review of the program by an external industry expert.

6. Provision for internship in government research institutions/laboratories of national repute is also made along with the core Biotechnology-led companies

The program commences with the student reporting to the selected industry. A periodical feedback from the industry and students is collected. The inputs from the industries and students are considered to make the process more robust for the subsequent cycles.
A schematic representation of the IndustryInternship is shown in figure 1 as shown below:

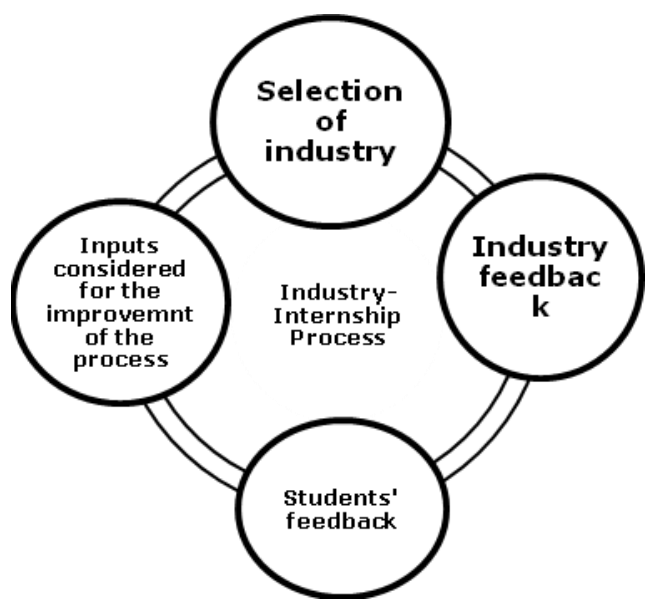

Fig. 1. Schematic representation of industry-internship Over a period of time, several Biotechnologybased companies, startups and government research organizations have accommodated the students for internship program. The student interns were deployed in different divisions of the organizations which included pilot production facilities, down Stream facilities, fermentation and bioprocess, Research \& Development (Microbiology, Biochemistry and Molecular Biology), quality control, quality assurance, medical services \& clinical development, animal studies and regulatory affairs.

C. Key Stake Holders in the Industry-Internship Process:

The following figure no. 2 represents the key stake-holders and their interaction during the industryinternship process at KLE Technological University.

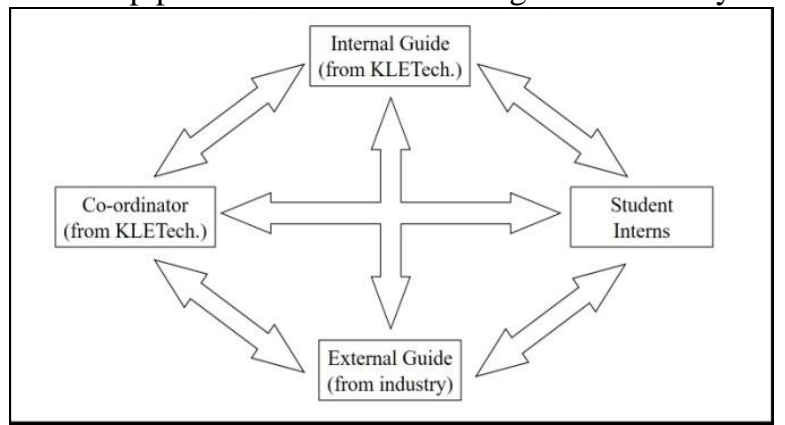

Fig. 2. Stake-holders in Industry-Internship Program (Subrmanian et al, 2012, modified)

D. Assessment, monitoring and feedback of the program:

The performance of the student interns was assessed in two modules: industry-training module and industry-project module. Industry training module of 6 credits with In Semester Assessment and End semester Assessment for 80 and 20 marks respectively. Similarly the industry project module comprised 14 credits with In 
Semester Assessment and End semester Assessment for 50 marks each. The assessment was rubrics based and reviewed by an external examiner from industry expert.

The internship students were kept in communication loop and monitored during the internship tenure by their respective departmental internal guide assigned to them. The faculty also visited in person, some industries, interacted with the student interns and their industry supervisors regarding their progress and performance.

A formal written feedback from both, the student interns (Appendix 1 ) and industries during the industry visit of faculty (Appendix 2) along with an online feedback was collected to assess their performance and to improve upon the process for subsequent cycles.

The detailed list of Biotechnology companies and research organizations providing internship opportunities are given in Appendix 3.

\section{RESULTS:}

A. Industry-internship as a sustainability model

The industry-internship program with the stake-holders and their inputs as key components has been evolving as a stable model over a period of time as shown in figure 3.

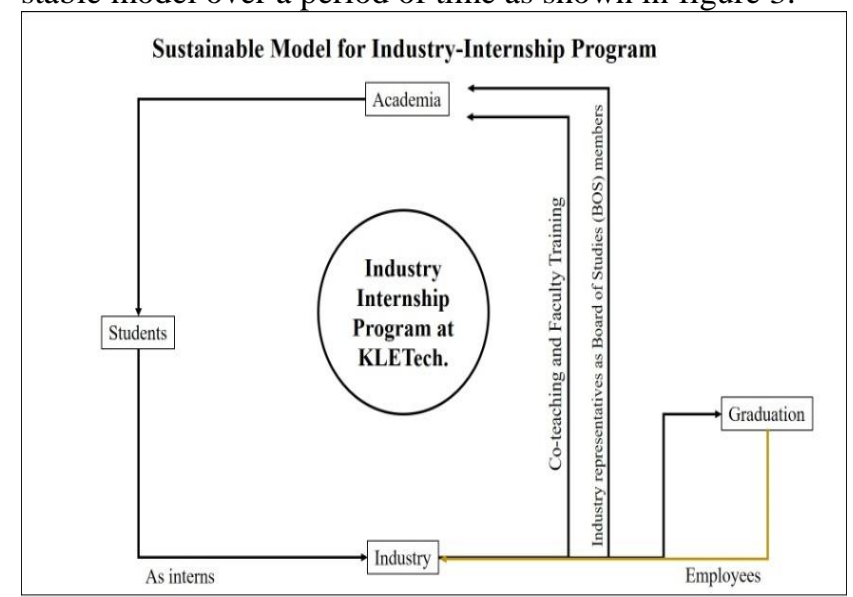

Fig.3. Sustainability model for Industry-Internship Program

The program has been instrumental in establishing and maintaining rapport with domain industry partners. Coteaching of the selected course content as partial delivery and faculty training in industries have been possible because of the program. Interaction with the industry experts has made it possible to include them as members of Board of Studies which has resulted in updating and redesigning of the curriculum periodically to meet industry expectations and

B. Number of internships year-on-year

Ever since the inception of the internship program in the academic year 2014-15, the number of internships has increased steadily over five years (from 17 internships in 2014-15 to 69 during 2018-19). The following graph (figure no.4) shows the year-on -year trend of increase in the industry-internship numbers in the department of Biotechnology.

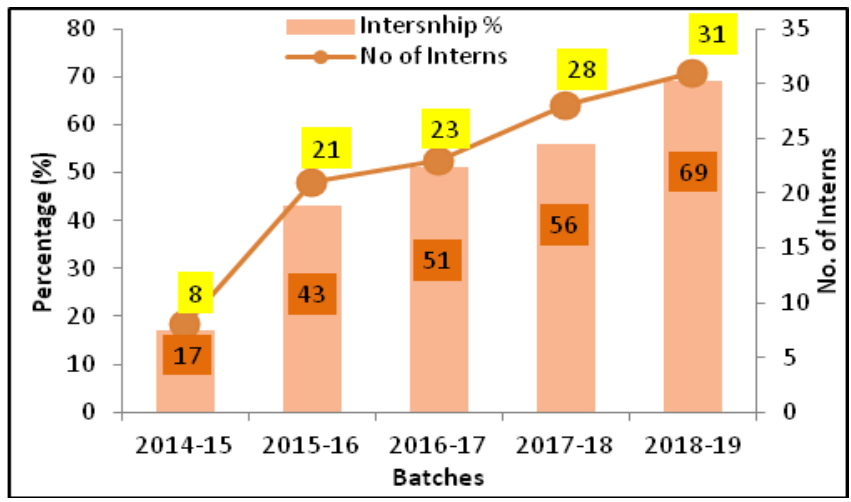

Fig.4. Number of placements year-on-year (2014-15 to 2018-19)

C. Program outcomes addressed through industryinternship.

The internship model has been helpful in addressing some of the program outcomes as shown in the Table 1 below.

Table 2. Program OUtcomes (PO) ADDRESSED THROUGH INDUSTRY INTERNSHIP PROGRAM.

\begin{tabular}{|l|l|l|}
\hline Sl. No. & $\begin{array}{l}\text { PO/ PSO } \\
\text { number }\end{array}$ & $\begin{array}{l}\text { Program Outcome/ Program Specific } \\
\text { Outcome }\end{array}$ \\
\hline 1 & PO-3 & Design/development of solutions \\
\hline 2 & PO-5 & Modern tool usage \\
\hline 3 & PO-6 & The engineer and society \\
\hline 4 & PO-7 & Environment and sustainability \\
\hline 5 & PO 11 & Project management and finance \\
\hline 6 & PSO-13 & Good Lab Practices (GLP) \\
\hline 7 & PSO-14 & Process \& Product Development \\
\hline 8 & PSO-15 & Research aptitude \\
\hline
\end{tabular}

D. Feedback from students and industries

The feedback from internship students $(n=28)$ reflected that the students felt the program was useful for increasing the prospects of jobs and was very helpful in enhancing the domain skill-sets and was a great value addition to their academic career.

The following figure 4 reflects the feedback of the student interns regarding internship program 


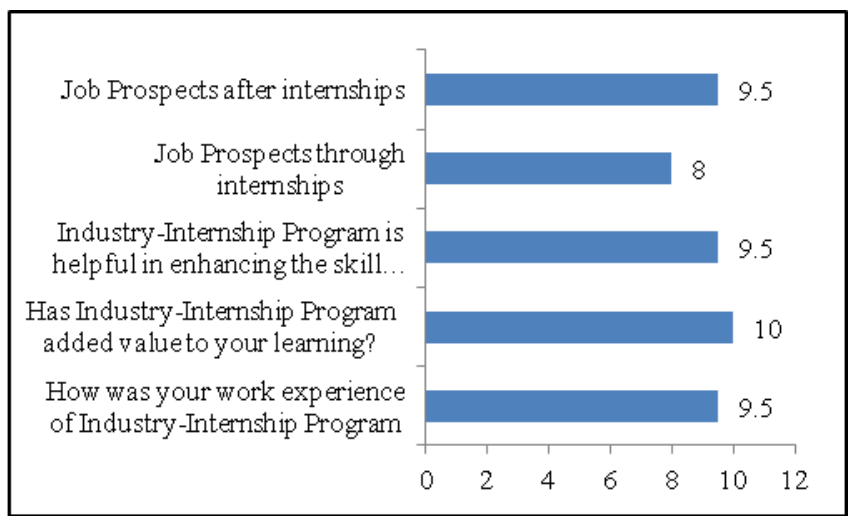

Figure 4. Feedback of students regarding internship
program

The participating industries too were satisfied with the tenure of 6 months. Overall analysis of the feedback by the industries revealed that the students showed good attitude and demonstrated good domain knowledge, coherence of team-work, soft-skills and oral \& written combination abilities. The following figure 5 shows the feedback by the industries.

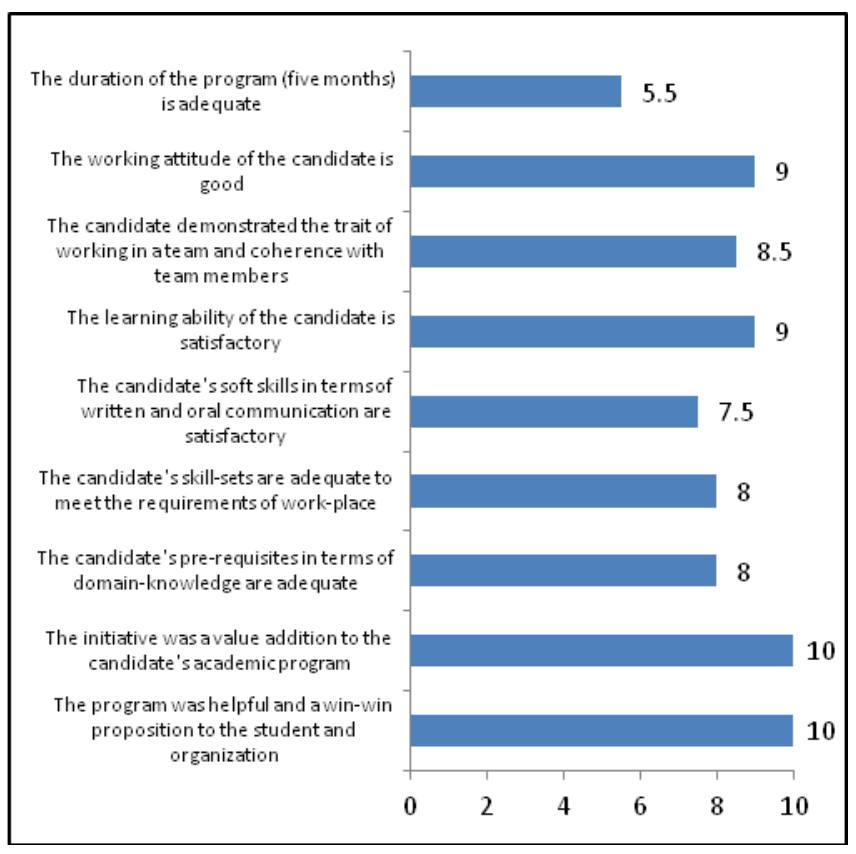

Figure 5. Feedback of industries regarding internship program and internship candidates

E. Challenges faced in the process:

The exercise of implementing the internship program came with a host of challenges. Some of the challenges faced are as follows:
1. Initially the students were reluctant to opt for the internship program due to inertial nature. The barrier needed to be removed through counseling and apprising them of the advantages he program offers.

2. Often the students had initial difficulties in getting acquainted to the new workplace and culture away from comforts of home.

3. More focused efforts are needed to convert the internship into placements .

4. There exists a challenge of striking a right match between the interest $\&$ expectations of the student and the industry profile he is working as intern.

\section{CONCLUSION:}

The industry-internship program has been successful in the Department of Biotechnology and has raised new aspirations in the students seeking career in the domain of Biotechnology. While the students get a feel of working on live projects, they also enhance their chances of securing a placement post internship based on their experience of six months as intern in the domain industry. The program has brought tangible benefits to students in terms of placements, work- experience, improved academic performance and intangible benefits through skill enhancement and making informed choice towards their career goals. The department too has been beneficiary in terms of improving the placements record, addressing the program outcomes, networking with industry professionals and meeting the accreditation related parameters.

\section{ACKNOWLEDGMENT}

The authors thank Dr. Ashok Shettar, Honorable Vice-Chancellor, KLE Technological University, Dr. N.H. Ayachit, Registrar, KLE

Technological University, Prof. B.L. Desai, Executive Dean, KLE Technological University and Dr. P.G. Tewari, Principal, B.V. Bhoomaraddi College of Engineering and Technology, Hubballi for their constant encouragement and support. We extend our thanks to all the industries and organizations for providing internship opportunities and extending their invaluable support. 


\section{REFERENCES}

[1]. Burnett, S. (2003) The future of accounting education: A regional perspective, Journal of Education for Business, 78(3), 129-134.

[2]. Busby, G. Brunt, P. and Baber, S. (1997) Tourism sandwich placements: An appraisal. Journal of Tourism Management, 18(2), 105-110.

[3]. Cannon, J.A., and Arnold, M.J. (1998) Student expectations of collegiate internship programs. Journal of Education for Business, 73(4), 202-205.

[4]. Carlson, R. (2016) Estimating the biotech sector's contribution to the US economy. Nature Biotechnology, 34(3), 247-255.

[5]. Cates-McIver, L. (1999) Internships and co-op programs, a valuable combination for collegians, Black Collegian, 30(1), 84-87.

[6]. Chang, D. and Chu, P. (2009) University-Industry Cooperation in Action: A Case Study of the Integrated Internship Program (IIP) in Taiwan, Journal of Hospitality \& Tourism Education, 21(1), 6-16.

[7]. Chen, T. and Shen, T. (2012) Today's intern, tomorrow's practitioner?-The influence of internship programmes on students' career development in the Hospitality Industry, Journal of Hospitality, Leisure, Sport \& Tourism Education, 11(1), 29-40.

[8]. Collins, A.B. (2002) Gateway to the real world, industrial training: dilemmas and problems, Tourism Management, 23(1), 93-96.

[9] Hite, R. and Bellizi, R. (1986) Students expectations regarding collegiate internship programs in marketing, Journal of Marketing Education, 8(3), 41-49.
[10]. Khan, R. and Gogos, A. (2013) Online Mentoring for biotechnology graduate students: An industry academia partnership, Journal of Asynchronous Learning Networks 17(1), 89-107.

[11]. Mascarelli, A. (2013) Environmental puzzle solvers, Nature, 494, 507-509.

[12]. Miner, J.B. and Crane, D.P. (1995) Human Resources Management. New York: Harper Collins.

[13]. Neuman, H. (1999) Internships. Career World. 27(6), 16.

[14]. Nugent, K.L. and Kulkarni, A.S. (2013) An interdisciplinary shift in demand for talent within the biotech industry, Nature Biotechnology, 31(9) 853855.

[15]. Philp, J. (2018) The bioeconomy, the challenge of the century for policy makers, New Biotechnology, 40(Part A), 11-19.

[16] Shet, A.R., Hungund, B.S., Yaraguppi, D.A., Tennalli, G.B., Patil, L.R., Sharanappa, A., Desai, S.V., Muddapur, U.M., Hombalimath, V.S. and Bagewadi, Z.K. (2017) Theme-Based Mini Project Implementation for Basic Skill-Set Development in Biotechnology, Journal of Engineering Education Transformations, 30(4), 73-77.

17] Shet, A.R., Hungund, B.S., Yaraguppi, D.A., Tennalli, G.B., Patil, L.R., Sharanappa, A., Desai, S.V., Muddapur, U.M., Hombalimath, V.S. and Bagewadi, Z.K. (2017) Theme-Based Minor Project Implementation for Basic Skill-Set Development in Biotechnology, Journal of Engineering Education Transformations, 30(4), 73-77.

[18]. Subramanian, R. Nagappan, A. Mathew and I.R. A Win-Win Dual Internship Model for Turning Graduates Employable, International Journal for CrossDisciplinary Subjects in Education, 3(4), 888-897. 


\section{APPENDICES}
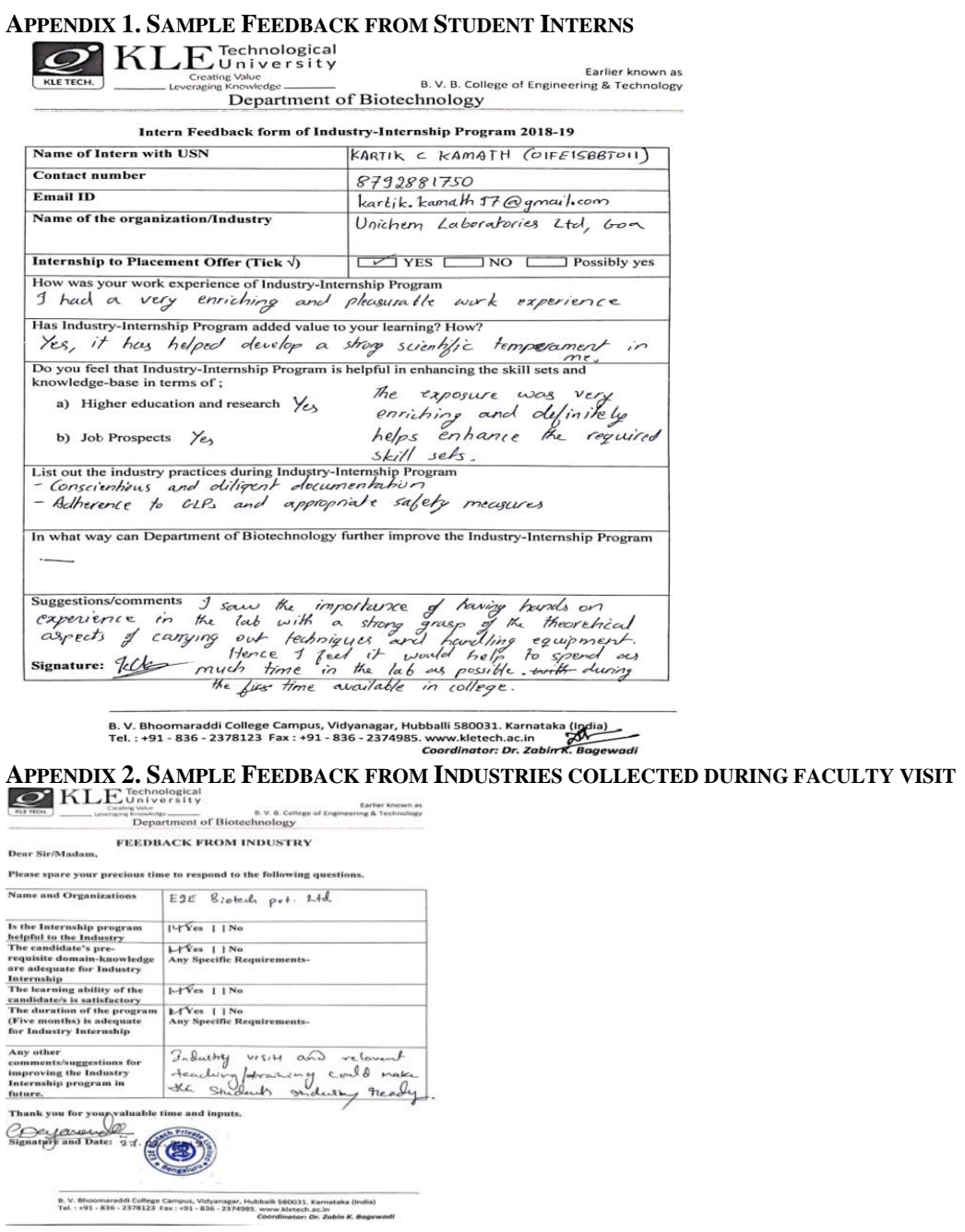

APPENDIX 3. LIST OF BIOTECHNOLOGY COMPANIES/RESEARCH ORGANIZATIONS PROVIDING INDUSTRY INTERNSHIPS.

\begin{tabular}{|l|l|l|l|}
\hline $\begin{array}{l}\text { SI. } \\
\text { No. }\end{array}$ & \multicolumn{3}{|c|}{ Industry/Research organizations providing Internships } \\
\hline 1 & Biocon Pvt. Ltd. Bengaluru. & 14 & Bhat Biotech. Bengaluru. \\
\hline 2 & Cipla Pvt. Ltd. Goa and Mumbai. & 15 & Abhiruchi Probiotics Pvt. Ltd. Pune. \\
\hline 3 & Himalaya Drug Company. Bengaluru. & 16 & Anthem Biosciences. Bengaluru. \\
\hline 4 & Unichem Laborotaries.Goa. & 17 & Bhat Serum and Vaccines. Mumbai. \\
\hline 5 & Serum Institute of India. Pune. & 18 & Prosetta Pvt. Ltd. Mysore \\
\hline 6 & National Chemical Laboratory. Pune. & 19 & Supreem Pharmaceuticals Ltd. Mysore. \\
\hline 7 & Aurigene Discovery Technologies Pvt. Ltd. Bengaluru. & 20 & Suez India Pvt. Ltd. Bengaluru. \\
\hline 8 & Novozymes. Bengaluru & 21 & E2E Biotech. Bengaluru. \\
\hline 9 & Pentavalent Biosciences. Bengaluru. & 22 & $\begin{array}{l}\text { ITC Life Sciences and Technology Centre. } \\
\text { Bengaluru. }\end{array}$ \\
\hline 10 & Bioplus Life Sciences, Bengaluru. & 23 & Biogenomics Pvt. Ltd. Mumbai. \\
\hline 11 & Shilpa Medicare Pvt. Ltd. Hubballi. & 24 & Sami Labs. Bengaluru. \\
\hline 12 & Prajna Biosciences. Hubballi. & 25 & Cytxon Biosolutions Pvt. Ltd. Hubballi. \\
\hline 13 & Chemogenesis Pvt. Ltd. Hubballi. & & \multicolumn{2}{l|}{} \\
\hline
\end{tabular}

